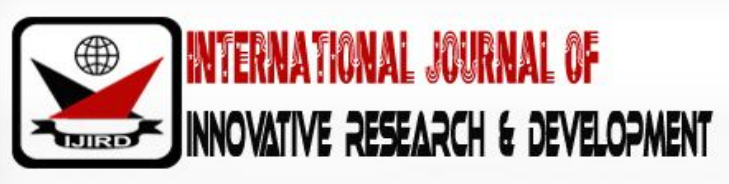

ISSN 2278 - 0211 (Online)

\section{Influence of School Feeding Program on Enrolment Rate in Public Preschools in Langata Subcounty, Nairrobi, Kenya}

\author{
Evanson. M. Murlithi \\ Lecturer, Department of Educational Communication and Technology, University of Nairobi, Kenya \\ Carren Akinyi Oluoch \\ M.Ed. Student, Department of Educational Communication and Technology, University of Nairobi, Kenya
}

\begin{abstract}
:
The study focused in examining the impact of school feeding program on enrolment in public preschools in Langata subcounty. School feeding programs usually help children to remain in school through enrolment enhancement and reducing absenteeism; and once the children are in school, the programs contribute to their learning, through avoiding hunger and enhancing their cognitive development. The specific objectives of the study were; to examine the influence of take home rations on the enrolment rate in public preschool in Langata sub-county, to determine the influence of onsite meals on the enrolment rate in public preschools in Langata sub-county and; to examine the influence of daily recommended allowances on the enrolment rate in public preschools in Langata sub-county. The study used descriptive research design to acquire information. The population for the research was the head teachers and two public preschool teachers within public schools in Langata Sub-County. The total sample respondents were 42 drawn from the 14 public primary schools within Langata subcounty. Random sampling was utilized in selecting the ECDE teachers in schools with more than two teachers. The acquired data was analyzed using descriptive statistics which included the mean, frequencies and percentage. This was done using Statistical Package for Social Sciences ( SPSS version 23.0). The study concluded that the implementation of the school feeding program has been one of the main strategic tools that have been utilized across institutions to foster enrolment rates. The study findings showed that different aspects of the programs such as the take home rations have fostered the retention rates among students. Similarly, the adoption of recommended daily allowances has been associated with better performance among pupils as it enhances the mental growth and acuity among children. The study further concluded that onsite meals are a key factor motivating attendance and retention rates within schools as children are sure of availability of meals in school. Further availability of onsite meals has been associated positively with enrolment rates within schools. There is a general increase in the enrolment rates within the public primary school sector. The study recommended that the government should enhance their resource allocation towards the support of the school feeding programme across the country.
\end{abstract}

Keywords: Enrolment rates, onsite meals, take home rations, school feeding program

\section{Introduction}

The United Nations is commitment to address the challenges resulting from advancing globalization in the formulation of the Sustainable development Goals (SDGs). The goals pay more attention to eradication of extreme hunger and poverty by 50\% in 2015 (United Nations Organization, 2005a). The recommendation of The United Nations Hunger Task Force on methods to achieve the first MDG in halving hunger by 2015(UNHTF, 2004), is the implementation of school feeding programs with locally produced foods rather than imported food (aid). The UNHTF considers school feeding programs to be a good combination of education and agriculture. Their point of view is that SFPs (school feeding programs) could increase school attendance. It further recommends comprehensive community and school-based feeding programs that include not only school feeding, but also systematic deworming, micronutrient supplementation and take-home rations. All these gradients aim at improving quality of education systems in schools, keeping children healthy and engaging the community (UNO, 2005b).

In the recent past, many countries have initiated the school feeding programs. For instance, 72 countries, covering 16.6 million school children had school feeding program under World Food Program in the year 2004, (WFP, 2005). The feeding program aims at achieiving the two millennium goals of poverty and hunger eradication and bridging of gender disparity gap. According to Hutchinson et al. (2006) school feeding in developing countries aim at increasing school enrolment, reducing absenteeism due to illness and decreasing drop-out. In many countries, school feeding programs is one of the key incentives to encourage children, especially girls, most poor and vulnerable children to attend school. 
School feeding program also serve as an incentive for poor households to send their children to school. The school attendance rates are lowest in poor households; therefore, providing school meals to children in the qualifying families can be correspondent to adding an extra 10\% to average household incomes. In this way, school feeding program serve as social safety net for poor households (WFP, 2006). Nonetheless, there are concerns in school feeding programs: School feeding survey in Malawi showed that $77 \%$ of children eat less food at home after school meals as supported by $82 \%$ of caregivers. Other household members particularly children benefit from extra food (Mutangadura et al, 2003).

\subsection{Statement of the Problem}

Kenyan schools have embraced feeding programs as directed by the provisions of the 2005 Sessional Paper on Education that was accepted by the Kenyan legislative body. Kenyan school feeding programs are contained as part of the four elements in the school health and nutrition agenda, which include increasing awareness of adequate culturally appropriate nutritious meals amongst school age children. In 2009, the government began a locally developed SFP initiative targeting 550,000 children and students in response to the 2008 National Nutrition and Food Security Policy supported by WFP. The Free Primary Education policy of 2003 brought major milestones in the education sector. Enrolment rates skyrocketed and most new entrants into the system were children from vulnerable backgrounds. This great step by the government however came with its challenges. Soon after kicking off, drop-out cases started being reported, studies by the Ministry of Education (2003) established that children could not be sustained in school due to hunger that had hit most parts of the country. The government then resolved to re-introduce the school feeding program.

\subsection{Purpose of the Research}

The purpose of this study was to examine the influence of School Feeding Program on Enrolment Rate in Public Preschools in Langata Sub County, Nairobi County, Kenya.

\subsection{Research Questions}

- What is the influence of take home rations on the enrolment rate in public preschool in Langata sub-county?

- What is the influence of onsite meals on the enrolment rate in public preschool in Langata sub-county?

- What is the influence of daily recommended allowances on the enrolment rate in public preschool in Langata subcounty?

\section{Literature Review}

\subsection{Take Home Rations and Enrolment}

In a study on 32 Sub-Sahara African countries, it was shown that providing food in school under the Food for Education (FFE) scheme contributed to increased enrolment in schools by $28 \%$ for girls and $22 \%$ for boys within one year (Gelli, et al., 2007). The enrollment pattern showed varies after one year depending on the type of FFE program; that is whether the provision of food in school was combined with take home rations or was served alone. Girls enrolment increased by 30\% in the subsequent year in school that provides both onsite and take home meals, (Gelli, et al., 2007).

Also, the United Nations reported that providing children with take-home rations after onsite meals increase enrollment in 32 countries and particularly beneficial to the girl child in primary school (WFP, 2009). Pakistan tried to solve enrolment challenges amongst girls in 1994 by providing snacks of rice to their families. Parents were encouraged to send their children to school especially girls and this led to increase of enrolment of girls (WFP, 2000). In India, Afridi (2011) found that a national meal program led to increase in attendance among girls (but not boys).

The school feeding programs serves as a motivation factor for enrolment especially in the developing countries such as Kenya. The on-site meals and take-home rations attract pupils to attend school (WFP, 2014). School feeding programs that offers meals regularly to the pupils is attractive and provides social protection options by providing dual development issues simultaneously. Impoverished families have both educational and social protection benefits from these programs as depicted in (World Bank, 2006).

Take-home meals improve mathematics scores for older children thus improving their performance on their primary leaving examination elaborated by (Adelman, et al; 2008) in their studies in Ugandan schools. This improvement in mathematics and literacy is revealed in children who delayed beginning their schooling. In addition, the feeding interventions improved their performance on one test of cognitive function and further evidence on meta-analysis of controlled before-andafter studies found an improvement of 0.66 SD score in mathematics test (Kristjansson, et al; 2007). Despite all the above studies providing sufficient literature evidence none of the studies focused on preschool children or essentially considered a peri-urban area like Langata sub-county.

\subsection{Onsite Meals and Enrolment}

The pupils' enrolment and class attendance are not consistent in the classrooms for teaching and learning processes. The World Bank reports that $30 \%$ of the malnourished children under five years, while $65 \%$ complete primary school at the right age in low income countries (Ahmed, 2004). The school drop out that result from poor parental homes is at $60 \%$ girl 
child globally as reported by UNICEF (2000), however, the school feeding programs have escalated the pupils' enrolment and school attendance. Adelman, et al. (2008) showed that there was a link between school meals, learning achievement and general school performance

First, since the meals improves class attendance, the children spent more time learning improving their school performance and minimizing the probabilities of school drop-out. However, this is dependent on other factors like school quality, availability of learning materials and teachers quality. Thus, unless properly implemented, school feeding has rather the potential to worsen drop-outs (Dheressa, 2011).

Second, improved nutrition enhances pupil participation and performance in both short and over long run. In short run, the school meals could alleviate hunger and make children concentrate and learn better to improve their academic performance hence reducing school drop-out. In long-term, school meals enhance learning by improving the nutritional status of children affecting their learning process, (Ahmed, 2004).

In the study by Ahmed (2004) in Bangladesh, School Feeding Program was found to have statistically significant negative impact on student drop-out. This study revealed that the primary school drop-out rate was $29 \%$ while the completion rate was $6 \%$ higher in control rural areas. Espejo (2009) found that the feeding program reduces the likelihood of school dropout by $7.5 \%$

\subsection{Daily Recommended Allowances and Enrolment}

In Iraq, the SFP was undertaken to support the Ministry of Education in helping the vulnerable people. Under the programme, the children receive 80 grams nutritious dates fortified with a range of vitamins. The World Food Programme experience for the last 45 years, show that by providing at least one nutritious meal daily, boosts enrolment and promotes regular attendance. Furthermore, parents were motivated to send their children to school instead of keeping them at home (WFP \& World Bank, 2009).

A study by (Belot \& James, 2009).in England explains the educational benefits from improved food quality for children, the comparison was made on London based primary schools that shifted from low-budget processed foods toward healthier options and found significant improvements in English and Sciences. This study implies that food quality affects academic results even for children in a rich country who are not undernourished. The study further indicates that by ensuring the recommended daily portions are provided to children this would increase their mental acuity and sharpness in class. Future studies should be considered in low-income settings in Kenya to confirm the relationship between meat consumption, milk as energy supplement and their significant impact on education performance (Whaley, et al; 2003). However, both empirical studies do not take into consideration the enrolment rate in preschool children. Furthermore, the time gaps in the study may render their findings structurally not reflective of the current research.

A study in Huaraz, Peru by (Ahmed, 2004) found that the attendance rate of fourth and fifth grade student increased by $0.58 \%$ due to school breakfast meals and declined by $2.92 \%$ in control schools (Adelman \& Gilligan, 2008). The evaluation took place in 30 days after the start of the breakfast program alongside the program implementation in control schools

\section{Research Methodology}

The study used descriptive research design (Mugenda \& Mugenda, 2003). The population for the research was the head teachers and two public preschool teachers within public schools in Langata Sub-County; hence 3 respondents per school. The total sample respondents were 42 drawn from the 14 public primary schools within Langata sub-county. Random sampling was utilized in selecting the ECDE teachers in schools with more than two teachers. Reliability of the instruments was determined. The study adopted all variables with a Cronbach Alpha of above 0.7.

\section{Findings and Discussion}

The table below presents the respondents' level of agreement on influence of Take Home Rations and Enrolment rate

\begin{tabular}{|c|c|c|c|c|c|c|c|}
\hline Statements & $\begin{array}{c}\text { Strongly } \\
\text { Agree } \\
(\mathbf{\%})\end{array}$ & $\begin{array}{c}\text { Agree } \\
\mathbf{( \% )}\end{array}$ & $\begin{array}{c}\text { Moderately } \\
\text { Agree (\%) }\end{array}$ & $\begin{array}{c}\text { Disagree } \\
\mathbf{( \% )}\end{array}$ & $\begin{array}{c}\text { Strongly } \\
\text { Disagree } \\
\mathbf{( \% )}\end{array}$ & $\begin{array}{c}\text { Mean } \\
\text { Std. } \\
\text { Dev }\end{array}$ \\
\hline $\begin{array}{c}\text { Increasing take home rations reduces } \\
\text { absenteeism in students }\end{array}$ & 14 & 15 & 60 & 5 & 6 & 2.74 & 1.300 \\
\hline $\begin{array}{c}\text { Increasing take home rations increases the } \\
\text { students uptake ration }\end{array}$ & 18 & 11 & 52 & 12 & 7 & 2.79 & 1.182 \\
\hline $\begin{array}{c}\text { Increasing levels of take home rations helped } \\
\text { bridge disparity gaps in enrolment }\end{array}$ & 15 & 12 & 51 & 10 & 12 & 2.92 & 1.158 \\
\hline $\begin{array}{c}\text { There is reduced disparity in enrolment in } \\
\text { preschool children }\end{array}$ & 14 & 12 & 55 & 8 & 11 & 2.9 & 1.211 \\
\hline $\begin{array}{c}\text { Increased take home rations fostered } \\
\text { performance in students }\end{array}$ & 12 & 15 & 53 & 7 & 13 & 2.94 & 1.245 \\
\hline
\end{tabular}

Table 1: Respondents' Level of Agreement on Influence of Take Home Rations and Enrolment Rate 
The results indicated that majority of the respondents were in agreement that; increasing take home rations reduces absenteeism in students as shown by a mean score of 2.74 and a standard deviation of 1.300, Increasing take home rations increases the students' uptake ration as shown by a mean score of 2.79 and a standard deviation of 1.182, Increasing levels of take home rations helped bridge disparity gaps in enrolment as shown by a mean score of 2.92 and standard deviation of 1.158, there is reduced disparity in enrolment in preschool children as shown by mean score of 2.90 as shown by standard deviation of 1.211. Increased take home rations fostered performance in students as shown by a mean score of 2.94 and a standard deviation of 1.245. The above findings conform to the observations of Gelli et.al (2007) who indicated that provision of food by World Food Programme increased enrolment rates at between 22\%-28\% in public schools. Similarly, Afridi (2011); agreed that SFP encouraged enrolment and reduced absenteeism in schools. The findings are in general in agreement with WFP (2014) report in Kenya that indicated that serving lunch at school and offering take-home rations fostered enrolment rates in Kenyan schools. The school feeding programs serves as a motivation factor for enrolment especially in the developing countries such as Kenya. The onsite meals and take-home rations attract pupils to attend school (WFP, 2014). School feeding programs that offers meals regularly to the pupils is attractive and provides social protection options by providing dual development issues simultaneously. Impoverished families have both educational and social protection benefits from these programs as depicted in (World Bank, 2006). In addition, the feeding interventions improved their performance on one test of cognitive function and further evidence on meta-analysis of controlled before-and-after studies found an improvement of 0.66 SD score in mathematics test (Kristjansson, et al; 2007).

The table below presents findings on Respondents' level of agreement with regard to Onsite Meals and Enrolment rate

\begin{tabular}{|c|c|c|c|c|c|c|c|}
\hline Statements & $\begin{array}{c}\text { Strongly } \\
\text { Agree } \\
\mathbf{( \% )}\end{array}$ & $\begin{array}{c}\text { Agree } \\
\mathbf{( \% )}\end{array}$ & $\begin{array}{c}\text { Moderately } \\
\text { Agree (\%) }\end{array}$ & $\begin{array}{c}\text { Disagree } \\
\mathbf{( \% )}\end{array}$ & $\begin{array}{c}\text { Strongly } \\
\text { Disagree } \\
\text { (\%) }\end{array}$ & $\begin{array}{c}\text { Mean } \\
\text { Std. } \\
\text { Dev }\end{array}$ \\
\hline $\begin{array}{c}\text { Increasing onsite meals foster school } \\
\text { attendance }\end{array}$ & 13 & 15 & 59 & 5 & 8 & 2.8 & 1.008 \\
\hline $\begin{array}{c}\text { Increasing onsite meals increases the } \\
\text { students enrolment rate }\end{array}$ & 15 & 11 & 54 & 11 & 9 & 2.88 & 1.052 \\
\hline $\begin{array}{c}\text { Increasing onsite meals fostered students } \\
\text { learning ability }\end{array}$ & 14 & 12 & 52 & 10 & 12 & 2.94 & 1.23 \\
\hline $\begin{array}{c}\text { Increasing onsite meals motivated } \\
\text { students to spend more time in school }\end{array}$ & 12 & 14 & 54 & 13 & 7 & 2.89 & 1.269 \\
\hline $\begin{array}{c}\text { Increased onsite meals reduce dropout } \\
\text { rates in school }\end{array}$ & 13 & 14 & 53 & 7 & 13 & 2.93 & 1.648 \\
\hline
\end{tabular}

Table 2: Respondents' Level of Agreement with Regard to Onsite Meals and Enrolment Rate

According to the results in table 2 above, majority of the respondents were in agreement that; increasing on site meals foster school attendance as shown by the mean of 2.80 with a variation rate of 1.008 , increasing on site meals increases the students enrolment rate as shown by the mean value of 2.88 and minimal response dispersion as indicated by the standard deviation of 1.05, increasing on site meals fostered students learning ability among the respondents as shown by the mean value 2.94 and a standard deviation of 1.23. These responses were in agreement with Adelman, et al. (2008) who showed that there is a causal link between school meals and grade repetition, learning achievement and school performance.

Respondent were also in agreement that increasing on site meals motivated students to spend more time in school as shown by the mean value of 2.89 and a standard deviation of 1.269 indicating minimal variations in the mean responses, increased on site meals reduce dropout rates in school as shown by 2.93 a mean value and 1.284 standard deviation indicating relative deviation from the mean responses. The above results are also in line with the conclusions drawn by Espejo, (2009) who found that school meals reduce the likelihood of school dropping out by school by $7.5 \%$. Since the meals improves class attendance, the children spent more time learning improving their school performance and minimizing the probabilities of school drop-out. However, it is dependent on other factors like school quality, availability of learning materials and teachers quality. Thus, unless properly implemented, school feeding has rather the potential to worsen drop-outs (Dheressa, 2011). The reults agreee with the statement that improved nutrition enhances pupil participation and performance in both short and over long run. In short run, the school meals could alleviate hunger and make children concentrate and learn better to improve their academic performance hence reducing school drop-out. In long-term, school meals enhance learning by improving the nutritional status of children affecting their learning process, (Ahmed, 2004).

The table below presents findings on respondents' level of agreement on statements on influence of recommended Daily Allowance on Enrolment rate 


\begin{tabular}{|c|c|c|c|c|c|c|c|}
\hline Statements & $\begin{array}{c}\text { Strongly } \\
\text { Agree }\end{array}$ & Agree & $\begin{array}{c}\text { Moderately } \\
\text { Agree }\end{array}$ & Disagree & & Mean & $\begin{array}{c}\text { Std. } \\
\text { Dev }\end{array}$ \\
\hline $\begin{array}{c}\text { Increasing RDA reduces absenteeism in } \\
\text { students }\end{array}$ & 9 & 19 & 59 & 5 & 8 & 2.84 & 1.034 \\
\hline $\begin{array}{c}\text { Increasing RDA increases the students uptake } \\
\text { ration }\end{array}$ & 8 & 17 & 55 & 10 & 10 & 2.97 & .855 \\
\hline $\begin{array}{c}\text { Increasing levels of RDA helped bridge } \\
\text { disparity gaps in enrolment }\end{array}$ & 9 & 11 & 58 & 10 & 12 & 3.05 & 1.076 \\
\hline $\begin{array}{c}\text { There is increased students' motivation in } \\
\text { preschool children as a result of increased } \\
\text { recommended daily allowances }\end{array}$ & 11 & 13 & 56 & 13 & 7 & 2.92 & 1.457 \\
\hline Increased RDA fostered attention in students & 10 & 12 & 54 & 9 & 15 & 3.07 & 1.101 \\
\hline
\end{tabular}

Table 3: Respondents' Level of Agreement on Statements on Influence of

Recommended Daily Allowance on Enrolment Rate

There was an agreement among respondents that increasing RDA reduces absenteeism in students as shown by the mean value of 2.84 with a standard deviation of 1.034 showing relative dispersion in the responses. Respondents also were in agreement that Increasing RDA increases the students' uptake ration as shown by the mean value of 2.97 and there was low deviation from the mean value as shown by the standard deviation value of .855. The findings are supported by Adelman and Gilligan, (2008) who argued that nutritious breakfast meals in school increased attendance rates within primary schools. In regard to increasing levels of RDA, helped bridge disparity gaps in enrolment, there was an agreement among respondents as shown by the mean value of 3.05 with small dispersion in responses as shown by a standard deviation value of 1.076.

There was increased students' motivation in preschool children as a result of increased recommended daily allowances; the respondents were in agreement as shown by the mean value of 2.92 and a standard deviation of 1.457 . The results further showed that in regard to increased RDA fostered attention in students, the respondents were in agreement as shown by a mean value of 3.07 and a standard deviation of 1.101. The above findings are supported by Belot and James (2009) who indicated that quality food supplements in schools increased mental acuity and education outcomes among children. A study in Huaraz, Peru by (Ahmed, 2004) found that the attendance rate of fourth and fifth grade student increased by $0.58 \%$ due to school breakfast meals and declined by $2.92 \%$ in control schools (Adelman \& Gilligan, 2008). The evaluation took place 30 days after the start of the breakfast program alongside the program implementation in control schools.

\begin{tabular}{|c|c|c|c|c|c|}
\hline & & $\begin{array}{c}\text { Prevalence } \\
\text { Level of } \\
\text { School } \\
\text { Feeding } \\
\text { Programs } \\
\end{array}$ & $\begin{array}{c}\text { Take Home } \\
\text { Rations }\end{array}$ & $\begin{array}{c}\text { Recommended } \\
\text { Daily } \\
\text { Allowances }\end{array}$ & $\begin{array}{l}\text { Onsite } \\
\text { Meals }\end{array}$ \\
\hline \multirow{3}{*}{$\begin{array}{c}\text { Prevalence Level Of School } \\
\text { Feeding Programs }\end{array}$} & Pearson Correlation & 1 & $.356^{*}$ & $.365^{*}$ & .255 \\
\hline & Sig. (2-Tailed) & & .036 & .031 & .133 \\
\hline & $\mathrm{N}$ & 36 & 35 & 35 & 36 \\
\hline \multirow[t]{3}{*}{ Take-Home Rations } & Pearson Correlation & $.356^{*}$ & 1 & $.692^{* *}$ & $.352^{*}$ \\
\hline & Sig. (2-Tailed) & .036 & & .000 & .038 \\
\hline & $\mathrm{N}$ & 35 & 35 & 34 & 35 \\
\hline \multirow{3}{*}{$\begin{array}{l}\text { Recommended Daily } \\
\text { Allowances }\end{array}$} & Pearson Correlation & $.365^{*}$ & $.692^{* *}$ & 1 & $.423^{*}$ \\
\hline & Sig. (2-Tailed) & .031 & .000 & & .011 \\
\hline & $\mathrm{N}$ & 35 & 34 & 35 & 35 \\
\hline \multirow[t]{3}{*}{ Onsite Meals } & Pearson Correlation & .255 & $.352^{*}$ & $.423^{*}$ & 1 \\
\hline & Sig. (2-Tailed) & .133 & .038 & .011 & \\
\hline & $\mathrm{N}$ & 36 & 35 & 35 & 36 \\
\hline
\end{tabular}

Table 4: Pearson Correlation Matrix

*. Correlation Is Significant at the Both 0.01 And0.05 Level (2-Tailed)

The findings in the table.4 above indicate the Pearson correlation coefficients between school feeding program and enrolment rate in public preschools. The findings indicate a statistically positive and significant association between the variables. The results obtained showed a positive statistically significant relationship between take home rations and enrolment rates in public preschools as shown by $p=.356$, sig $=.036$. This shows that a unit change in take home rations will result in 0.356 increase in enrolment rate or $35.6 \%$ increase. The results further indicated that there was a positive statistically significant relationship between recommended daily allowances and enrolment rates in public preschools as shown by $\mathrm{p}=.365$, sig $=.031$. This shows that a unit change in recommended daily allowances will result in 0.365 increase in 
enrolment rate or $36.5 \%$ increase. The results also showed that there was a positive statistically significant relationship between onsite meals and enrolment rates in public preschools as shown by $\mathrm{p}=.255$, sig $=.133$. This shows that a unit change in recommended daily allowances will result in 0.255 increases in enrolment rate or $25.5 \%$ increase in enrolment.

\section{Conclusions}

The study concludes that the implementation of the school feeding program has been one of the main strategic tools that have been utilized across institutions to foster enrolment rates. The study findings have also showed that different aspects of the programs such as the take home rations have fostered the retention rates among students. Similarly, the adoption of recommended daily allowances has been associated with better performance among students as it enhances the mental growth and acuity among children.

The study further concludes that onsite meals within schools are key factor motivating attendance and retention rates within schools as children are sure of availability of meals in school. Further availability of onsite meals have been associated positively with enrolment rates within schools. It was also found that the availability of school learning facilities supplements the school feeding programme as a tool of enhancing the enrolment rates in public preschools. There is a general increase in the enrolment rates within the public preschools. This has translated in an upsurge of preschool to accommodate the growing population number. The findings of the study also conclude that in majority of the institutions the school feeding programme has been implemented with assistance from the government and other stakeholders by the donor community. The general Pearson correlation analysis concluded that there is a statistically positive relationship between the research variables as indicated.

\section{Recommendations}

- The government should enhance their resource allocation towards the school feeding programmes to supplement the feeding programmes being undertaken by donor agencies across the country.

- The school administration should engage parents, alumni of the institution, churches and other NGO's to help supplement the school feeding programmes and enhance the sustainability of the project.

- The availability of recommended daily allowances should be enhanced in order to foster mental growth of children. Further, availability of take-home rations should be encouraged to ensure that children have a sure meal at home to avoid absenteeism and dropout within the preschools.

- The school feeding programme should be expanded through better policy interventions and strategies that can allow for the feeding programmes to be undertaken even during holiday sessions especially where families have limited resources; this will help to ensure young children are fed continuously.

\section{References}

i. Adelman, S. and Gilligan, D and Lehrer, K. (2008). How Effective are Food for Education Programs? Critical Assessment of the Evidence from Developing Countries. Washington DC: International Food Policy Research Institute.

ii. Adelman, S. and Gilligan, O and Lehrer, K. (2009). The Impact of Alternative Feeding for Programs on Education Achievement and Cognitive Development in Northern Uganda, mimeo. International Food Policy Research Institute, Washington DC.

iii. Afridi, F. (2011). The impact of school meals on school enrolment: Evidence from rural India. Journal of Development Studies, 47(11), 1636-1656.

iv. Ahmed, A.U. (2004). The Impact of feeding children in school, Bangladesh. Journal of International Food Policy Research Institute, 23, 45-63.

v. Dheressa, D.K. (2011). Education in Focus: School Feeding Program School Participation Impacts: A case study in Dara Woreda of Sidama Zone, Southern Ethiopia. Thesis, Norwegian University of Life Sciences (UBM).

vi. Espejo, F. (2009). Home-grown School Feeding: A Framework to Link School Feedingprogram with Local Agricultural Production. Rome: World Food Program.

vii. Gelli, A. (2010). Food Provision in Schools in Low and Middle Income Countries: Developing an Evidenced Based Program Framework. HGSF Working Paper Series \#4. Partnership for Child Development (PCD).

viii. Gelli, A., Meir, U et al. (2007). Does provision of food in school increase girls' enrollment? Case study from schools in sub-Saharan Africa.Food and Nutrition Bulletin, 28.

ix. Hutchinson, S.E., Chang, C.L. and McGregor, S.M. (2006). School children's diets and participation in school feeding programs in Jamaica. Journal of Public Health and Nutrition, 1, 43-49.

x. Ministry of Education (MoE), (2003). Free primary education:-For Every child in primary school. Nairobi: Government Printer.

xi. Mugenda, O., and Mugenda, A. (2003). Research Methods: Qualitative and Quantitative Approaches. Act Press: Nairobi.

xii. Mutangadura, G.B., McLeod, J.J., Lamb, V. L. (2003). Variations in rates of primary school access and enrolments in SubSaharan Africa. International Journal of Educational Development, 32, 171-175.

xiii. Tomilson, M. (2007). School feeding in east and southern Africa. Improving food sovereignty or photo opportunity? Equine discussion paper number 46. 
xiv. UNICEF, (2000). The state of the world's children in UNICEF. New York: UNICEF.

xv. Wanjohi, A.M. (2010). Factors affecting sustainabile school feeding programme. Magadi Zone, in Kajiado County. https:/ / papers.ssrn.com/ sol3/ papers.cfm?abstract id=1665013

xvi. Belot, M and James, J. (2009). Healthy School Meals and Educational Outcomes. ISER Working Paper Series, Essex, UK: Institute for Social \& Economic Research.

xvii. Kristjansson, E., V. Robinson, M. Petticrew, B. MacDonald, J. Krasevec, L. Janzen, T. Greenhalgh, G. Wells, J. MacGowan, A. Farmer, B. J. Shea, A. Mayhew, and P. Tugwell, 2007. School Feeding for Improving the Physical and Psychosocial Health of Disadvantaged Elementary School Children. Cochrane Database of Systematic Reviews.

xviii. World Bank, (2006). Repositioning nutrition as central to development. Washington, D.C: Author.

xix. World Bank, (2012). Keep children in school while improving their learning and health. Scaling up school feeding program. http:/ / siteresource.worldbank.org/ EDUCATION/ Resources/ 2782001334777272566/ results2012-SBHDN-update -schoolfeeding.pd/ / f.

xx. World Food Programme, (2005). Global And Country School Feeding Reports From Lesotho, Malawi And The Gambia. ROME: WFP.

xxi. World Food Programme, (2004). School Feeding Programme: Why They Should Be Scaled Up Now? Tanzania: Author.

xxii. World Food Programme, (2006). Food For Education; Experts' Seminar: Reviewing The Evidence. Rome: WFP.

xxiii. World Food Programme, (2008). Draft School Feeding Policy: A Hunger Safety Net That Supports Learning, Health And Community Development. Rome, Italy: world food programme.

xxiv. World Food Programme, (2008). Global School Feeding Report. WFP School feeding support unit, Rome: Author.

xxv. World Food Programme (2009) Child Based Food for Education. Addis Ababa: author.

xxvi. . Langinger N. (2011) School Feeding Programme in Kenya: Transition to a Homegrown Approach. In Stanford Journal of

xxvii. International relations Vol XIII No.1 